\title{
PANCREATIC INVOLVEMENT IN LEPTOSPIROSIS
}

\author{
Maria Atanasova, Galya Gancheva, Penka Ilieva, Chrisima Tzvetanova, Iskra Simova \\ Department of Infectious Diseases, Epidemiology, Parasitology, and Tropical \\ Medicine, Medical University, Pleven, Bulgaria
}

\begin{abstract}
:
The research includes 84 patients with leptospirosis treated in Clinic at Infectious Diseases - Pleven. Mild course in $52,38 \%$, moderate in $19,05 \%$, and severe in $28,57 \%$ are established. Serum amylase level has been investigated in 37 cases. Increased rates are measured in $41,67 \%$ of mild cases (av. $279 \mathrm{U} / \mathrm{L}$ ), in $25 \%$ of moderate cases (av. $290 \mathrm{U} / \mathrm{L}$ ), and in $88,24 \%$ of severe cases(av. $937 \mathrm{U} / \mathrm{L}$ ). Significant difference between serum amylase levels of mild and severe cases is established $(p<0,02)$. Presumably immunological mechanisms of damage by participation of interleukins ( $\mathrm{IL}_{1}$, $\left.\mathrm{IL}_{6}, \mathrm{IL}_{8}\right)$ and tumor necrosis factor (TNF-a) are in the base of increased serum amylase level in leptospirosis. The functional changes of pancreas in leptospirosis are not fully clear and further research is needed.
\end{abstract}

Key words: leptospirosis, pancreas, serum amylase, interleukins.

Leptospirosis is an acute infectious disease caused by Leptospira interrogans - complex. The course of disease is in two phases - spirochaetemic and immune, with broad clinical spectrum. The clinical manifestations are well studied. More unclear is immunopathogenesis and the mechanism of damage in the pancreas.

AIM of this research is analysis of clinical and laboratory parameters, characterizing the pancreatic functions in leptospirosis.

\section{MATERIALAND METHODS:}

Retrospective (in part of the cases prospective) study in 84 patients with leptospirosis (1982 to 2004) is performed.

\section{RESULTS:}

Mild course (serum creatinine level below $200 \mu \mathrm{mol} /$ L) in $52,38 \%$ of cases, moderate (serum creatinine level between 200 and $600 \mu \mathrm{mol} / \mathrm{L}$ ) in $19,05 \%$, and severe course (serum creatinine level above $600 \mu \mathrm{mol} / \mathrm{L}$ ) in $28,57 \%$ have been established.

Abdominal pain localized in epigastria and left hypochondria and simulating acute surgery abdomen is presented in 7,31\%; pain in epigastria and right hypochondria - in $8,54 \%$, diffuse abdominal pain - in $4,89 \%$ of the patients. In $2,44 \%$ the pain is with irradiation to the scapulas and vertebral column. Persisting vomiting in $12,20 \%$ is observed. Pain at palpation of the abdomen presents in $8,54 \%$, and peritoneal irritation - in $2,44 \%$. The peristalsis is flaccid in $7,31 \%$.

Routine laboratory parameters: leucocytosis in $73,81 \%$, granulocytosis with extreme left shift - in 97,62\%, increased erythrocytes, sedimentation rate (ESR) - in $86,90 \%$, thrombocytopenia - in $42,86 \%$, increased fibrinogen above $4,6 \mathrm{~g} / \mathrm{L}$ - in $73,81 \%$; increased nitrogen parameters - blood urea nitrogen (BUN) above $8,3 \mathrm{mmol} / \mathrm{L}$ in $80,95 \%$ (av. $26,1 \mathrm{mmol} / \mathrm{L}$ ), serum creatinine level above $135 \mu \mathrm{mol} / \mathrm{L}$ - in 72,62\% (av. 303,2 $\mu \mathrm{mol} / \mathrm{L}$ ). Serum bilirubin is elevated in $70,24 \%$ (av. $167,9 \mu \mathrm{mol} / \mathrm{L}$ ) with prevalence of conjugated fraction. Aminotransferase activity is moderately elevated (range from 12 to $382 \mathrm{U} / \mathrm{L}$ ). Hyperglycemia in 64,63\% (av. $7,3 \mathrm{mmol} / \mathrm{L}$ ) and glycosuria in $26,84 \%$ are established. Serum amylase level is elevated in 59,45\% (av. 556U/L; range from 58 to $3960 \mathrm{U} / \mathrm{L}$ ).

A table 1 . includes average rates of laboratory parameters characteristic for pancreatic and renal functions.

Table 1. Laboratory parameters for pancreatic and renal functions in patients with leptospirosis.

\begin{tabular}{|c|c|c|c|c|c|c|}
\hline forms & \multicolumn{2}{|c|}{ mild } & \multicolumn{2}{c|}{ moderate } & \multicolumn{2}{c|}{ severe } \\
\cline { 2 - 7 } parameter & $\%>\mathrm{N}$ & av. & $\%>\mathrm{N}$ & av. & $\%>\mathrm{N}$ & av. \\
\hline $\begin{array}{c}\text { serum } \\
\text { amylase }\end{array}$ & 41,67 & 279 & 25 & 290 & 88,24 & 937 \\
\hline $\begin{array}{c}\text { serum } \\
\text { glucose }\end{array}$ & 2,44 & 5,9 & 8,54 & 6,3 & 78,94 & 10 \\
\hline $\begin{array}{c}\text { serum } \\
\text { creatinine }\end{array}$ & 83 & 120 & 100 & 210 & 100 & 535 \\
\hline
\end{tabular}

Significant difference in serum amylase levels between mild and severe $(p<0,02)$ and between moderate and severe forms $(p<0,02)$ are established.

Ultrasound observations reveal enlarged swelling pancreas in 2,44\% with hyperehogenic structure - in 7,31\%: hypoehogenic - in 3,66\%; fluid leakage in peripancreatic spaces - in 1,22\%. Pancreatic CT - scaning is performed in $2,44 \%$ and does not reveal pathological changes.

In one patient (with fatal outcome) focal pancreatic necrosis is established. 


\section{DISCUSSION:}

Leptospirosis is an acute infectious disease with multiorgan damage. In the spirochaetemic phase (4 to 7 days) leptospires spread to all organs and tissues.

The basic pathological changes are caused by glycolipoprotein cytotoxic factor which displaces host longchain fatty acids required in maintain vascular cell wall integrity. Going out control the mechanism of vassal lesions reflect in generalized systemic vasculitis allowing the migration and proliferation of spirochaetes into all organs and tissues. Most severe are renal and hepatic injuries. Except direct action of the cytotoxic factor is accepted the role of an endotoxin, which is obtained only in certain serotypes. In the same time nonspecific inflammatory factors are involved. Hypovolemia, systemic vasculitis, leading to blood hyperviscosity, low-graded intravascular coagulation compromise the microcirculation, resulting in stasis and tissue hypoxia $[2,4,5,6,9,14,16]$. Perhaps immunological mechanisms play important role in the tissue injury $[1,3,7,15$, 16].

The analysis of some basic aspects in the modern etiopathogenesis of acute pancreatitis establishes the following important moments: traditional reasons for appearing of acute pancreatitis are gallbladder diseases, alcoholism, drugs, and trauma. There are and more rare reasons as final stage of renal failure, infectious diseases (CMV, viral hepatitis A, B, C, Epstain-Barr, mumps, leptospirosis). The activated proteases impair permeability of the blood vessels because of that appears interstinal oedema with or without hemorrhages. The activated complement, cinins, calicrein participate actively in the genesis of DIC, circulator failure, shock. Released elasthasis from leucocytes in addition increase the damage of the elastic components of the blood vessels. Toxical effects upon the pancreatic vessels walls have free radicals. The immune system participate also actively. Serious abnormality in cell-mediated immunity are established $[1,8,9,10,11,12,13,16,17]$.

Clinically acute pancreatitis has been manifested with classical triad - dramatic abdominal pain with characteristic localization and irradiation, persisted vomiting and shock. Routinely used investigation of serum amylase hasn't full correlation with severity of the pancreatitis because in severe cases serum amylase level is not extremaly high $[9,11$, $14,15]$.

In our research only $2,44 \%$ of patients has clinically manifested symptom for pancreatic damage. Hence functional pancreatic disorders prevalence in leptospirosis. They appears in immune phase of the disease [4].

Clinically-immunological and pathomorphological aspects of the pancreatic injury in leptospirosis are not fully clear and require further research.

\section{REFERENCES:}

1. Божков Б., Д. Попова. Автоимунитет и автоимунни болести. Арсо, София, 1997, 9-45.

2. Илиев Б. и др. Инфектология, С., “М. Дринов”, 2001, 392-400.

3. Abdulkader RC, Daher EF, Camargo ED et al. Leptospirosis severity may be associated with the intensity of humoral immune response. Revisia de Instituto de Medicina Tropical de Sao Paolo, 44, 2002, 79-83.

4. Daher EF, et al. Pancreatic involvement in fatal human leptospirosis: clinical and pathological features. Rev do Inst de Med Trop de Sao Paulo, 2003, 45, 307-313.

5. Faine S. Lepotospirosis. In: Hausler WJ, Ir. Sussman M. eds. Topley and Wilson. Microbiology and Microbial Infections. $9^{\text {th }}$ ed. London: Amold; 1998, 849-869.

6. Farr RW. Leptospirosis. Clin. Inf. Dis., 1995, 21, 1-8.

7. Grewal H., A. Mohey, RL. Diu L. et al. Amelioration of the physiologic and bio- chemical changes of acute pancreatitis using an anti-TNF-a polyclonal antibody. An. J. Surg., 167, 1994, 214.

8. Ko AI., Galvao Reis, Ribeiro Dourado et al. Urban epidemic of severe leptospirosis in Brasil. Lancet, 354, 1999, 820825.

9. Kusske A., A. Rangione, M. Levis et al. Interleukin -10 reduces the severity of acute hemorrhagic pancreatitis in rats. Gastroenterology, 110/4, 1996, A, 407.

10. Miller G., D. Pritchard, R. Ritts et al. Effect of surgery on the quantity of lymphocyte subpopulation. J. Surg. Res. 21, 1996, 155-156.

11. Norman J., G. Fruk, M. Franz et al. Active Interleukin - $1\left(\mathrm{IL}_{1}\right)$ receptor required for maximal progression of acute pancreatitis. Ann, surg., 223, 1996, 163.

12. Reth M. The B cell antigen receptor complex and co-receptors. Immunology today, 16/7, 1995, 241-250.

13. Singh SS., Vijayachari P., Sinhe A.,
Sugunen AP., Pasheed MA., Seghal SC. Clinico-epidemiological study of hospitalized cases of severe leptospirosis. Indian Journal of Medicine Research. 109, 1999, 94-99.

14. Suzuki S., M.Masuda, Oht M. et al. Interleukin-6 (IL6) receptor monoclonal antibody improved severe acute pancreatitis in $\mathrm{IL}_{6}$ trangenic mice. Gastroenterology, 1999, 116/4, A, 1166.

15. Tschaikowsky K., N. Lehnert, A. Schiele et al. Prognostic value of immunomonitoring in patients with polytrauma and sepsis. British Journal of anaestesia, 199880 supp 1, 156.

16. Watkins S. Complement and clinical intervention. Ann. Anesth. Reanim. 4/2, 1985, 129-132.

17. Zaki SR. et al. In: Nelson Am. Horsburg Cr Jr. Eds. Pathology of Emerging Infections L, Washington, Dc: American Society For Microbiology, 1998, 73-92. 